\title{
Front Matter: Volume 8773
}

, "Front Matter: Volume 8773," Proc. SPIE 8773, Photon Counting Applications IV; and Quantum Optics and Quantum Information Transfer and Processing, 877301 (17 May 2013); doi: 10.1117/12.2030986

SPIE. Event: SPIE Optics + Optoelectronics, 2013, Prague, Czech Republic 


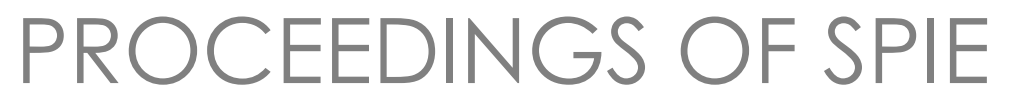

\section{Photon Counting Applications IV; and Quantum Optics and Quantum Information Transfer and Processing}

Ivan Prochazka

Jaromír Fiurásek

Roman Sobolewski

Editors

16-17 April 2013

Prague, Czech Republic

Sponsored and Published by

SPIE

Volume 8773 
The papers included in this volume were part of the technical conference cited on the cover and title page. Papers were selected and subject to review by the editors and conference program committee. Some conference presentations may not be available for publication. The papers published in these proceedings reflect the work and thoughts of the authors and are published herein as submitted. The publisher is not responsible for the validity of the information or for any outcomes resulting from reliance thereon.

Please use the following format to cite material from this book:

Author(s), "Title of Paper," in Photon Counting Applications IV; and Quantum Optics and Quantum Information Transfer and Processing, edited by Jaromír Fiurásek, Ivan Prochazka, Roman Sobolewski, Proceedings of SPIE Vol. 8773 (SPIE, Bellingham, WA, 2013) Article CID Number.

ISSN: 0277-786X

ISBN: 9780819495754

Published by

SPIE

P.O. Box 10, Bellingham, Washington 98227-0010 USA

Telephone +1 3606763290 (Pacific Time) · Fax +1 3606471445

SPIE.org

Copyright (C) 2013, Society of Photo-Optical Instrumentation Engineers.

Copying of material in this book for internal or personal use, or for the internal or personal use of specific clients, beyond the fair use provisions granted by the U.S. Copyright Law is authorized by SPIE subject to payment of copying fees. The Transactional Reporting Service base fee for this volume is $\$ 18.00$ per article (or portion thereof), which should be paid directly to the Copyright Clearance Center (CCC), 222 Rosewood Drive, Danvers, MA 01923. Payment may also be made electronically through CCC Online at copyright.com. Other copying for republication, resale, advertising or promotion, or any form of systematic or multiple reproduction of any material in this book is prohibited except with permission in writing from the publisher. The CCC fee code is 0277-786X/13/\$18.00.

Printed in the United States of America.

Publication of record for individual papers is online in the SPIE Digital Library.

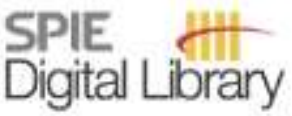

SPIEDigitalLibrary.org

Paper Numbering: Proceedings of SPIE follow an e-First publication model, with papers published first online and then in print and on CD-ROM. Papers are published as they are submitted and meet publication criteria. A unique, consistent, permanent citation identifier (CID) number is assigned to each article at the time of the first publication. Utilization of CIDs allows articles to be fully citable as soon as they are published online, and connects the same identifier to all online, print, and electronic versions of the publication. SPIE uses a six-digit CID article numbering system in which:

- The first four digits correspond to the SPIE volume number.

- The last two digits indicate publication order within the volume using a Base 36 numbering

system employing both numerals and letters. These two-number sets start with 00, 01, 02, 03, 04, $05,06,07,08,09,0 A, 0 B \ldots$. 0Z, followed by 10-1Z, 20-2Z, etc.

The CID Number appears on each page of the manuscript. The complete citation is used on the first page, and an abbreviated version on subsequent pages. Numbers in the index correspond to the last two digits of the six-digit CID Number. 


\section{Contents}

vii Conference Committee

\section{PART A Photon Counting Applications IV}

\section{SESSION 1 SOLID STATE PHOTON COUNTING}

877302 Silicon photomultipliers development at STMicroelectronics (Invited Paper) [8773-1] M. Mazzillo, F. Nagy, D. Sanfilippo, G. Valvo, B. Carbone, A. Piana, G. P. Fallica, S. Coffa, STMicroelectronics (Italy)

877303 Compact 32-channel time-resolved single-photon detection system (Invited Paper) [8773-2]

A. Cuccato, S. Antonioli, A. Gulinatti, I. Labanca, I. Rech, M. Ghioni, Politecnico di Milano (Italy)

877304 Figures of merit for CMOS SPADs and arrays [8773-3]

D. Bronzi, F. Villa, S. Bellisai, Politecnico di Milano (Italy); S. Tisa, Micro Photon Devices S.r.I. (Italy); G. Ripamonti, A. Tosi, Politecnico di Milano (Italy)

877305 Compact CMOS analog readout circuit for photon counting applications [8773-4] E. Panina, L. Pancheri, G.-F. Dalla Betta, Univ. of Trento (Italy); L. Gasparini, D. Stoppa, Fondazione Bruno Kessler (Italy)

877306 Buffer direct injection readout integrated circuit design for dual band infrared focal plane array detector [8773-5]

T.-P. Sun, Y.-C. LU, H.-L. Shieh, National Chi Nan Univ. (Taiwan); S.-F. Tang, W.-J. Lin, ChungShan Institute of Science and Technology (Taiwan)

\section{SESSION 2 PHOTON COUNTING APPLICATIONS I}

877308 Photon counting delay stability as a key factor for optical time transfer [8773-7] J. Blazej, I. Prochazka, Czech Technical Univ. in Prague (Czech Republic); J. Kodet, Czech Technical Univ. in Prague (Czech Republic) and Technische Univ. München (Germany)

877309 Photon counting Lidar for deep space applications: concept and simulator [8773-8] M. Vacek, V. Michalek, M. Peca, I. Prochazka, J. Blazej, Czech Technical Univ. in Prague (Czech Republic)

8773 OA High accurate range finding with SPADs at 1064nm [8773-9]

J. J. Eckl, Bundesamt für Kartographie und Geodäsie (Germany); K. U. Schreiber, Technische Univ. Muenchen (Germany) 
8773 OD Ultra-compact 32-channel system for time-correlated single-photon counting measurements [8773-12]

S. Antonioli, A. Cuccato, L. Miari, I. Labanca, I. Rech, Politecnico di Milano (Italy);

M. Ghioni, Politecnico di Milano (Italy), and Micro Photon Devices S.r.l. (Italy)

$8773 \mathrm{OE}$ The application of single photon detector technique in laser time transfer for Chinese navigation satellites [8773-13]

W. Meng, H. Zhang, Z. Zhang, Shanghai Astronomical Observatory (China); I. Prochazka,

Czech Technical Univ. in Prague (Czech Republic)

\section{SESSION 4 SUPERCONDUCTING PHOTON COUNTING}

8773 OG Proximitized NbN/NiCu nanostripes as new promising superconducting single-photon detectors (Invited Paper) [8773-15]

G. Pepe, L. Parlato, SPIN Napoli, CNR (Italy) and Univ. of Naples Federico II (Italy); C. Bonavolontà, M. Valentino, SPIN Napoli, CNR (Italy); C. De Lisio, SPIN Napoli, CNR (Italy) and Univ. of Naples Federico II (Italy); R. Cristiano, M. Ejrnaes, Istituto di Cibernetica, CNR (Italy); H. Myoren, Saitama Univ. (Japan); R. Sobolewski, Institute of Electron Technology, Warzawa (Poland) and Univ. of Rochester (United States)

\section{POSTER SESSION 1}

8773 OK Photoreadout statistics analysis during space objects image acquisition in large aperture telescope [8773-19]

Y. P. Shumilov, P. A. Bakut, V. G. Vygon, E. A. Grishin, V. D. Shargorodskii, Precision Systems and Instruments Corp. (Russian Federation)

$8773 \mathrm{OL}$ Thermoelectric nanowire single-photon detector [8773-20]

A. A. Kuzanyan, A. S. Kuzanyan, Institute for Physical Research (Armenia)

8773 OM Photon counting Lidar for deep space applications: demonstrator design [8773-21] V. Michálek, M. Vacek, Czech Technical Univ. in Prague (Czech Republic), and Výzkumný a Zkusební Letecký Ústav, a.s. (Czech Republic); I. Procházka, J. Blažej, Czech Technical Univ. in Prague (Czech Republic); M. Peca, Czech Technical Univ. in Prague (Czech Republic), and Výzkumný a Zkusební Letecký Ústav, a.s. (Czech Republic)

\section{Part B Quantum Optics and Quantum Information Transfer and Processing SESSION 5 OPTICAL QUANTUM INFORMATION PROCESSING}

8773 OP Photonic hybrid multidimensional systems and their application in quantum communication [8773-31]

V. D'Ambrosio, E. Nagali, Univ. degli Studi di Roma La Sapienza (Italy); L. Marrucci, Univ. degli Studi di Napoli Federico II (Italy); F. Sciarrino, Univ. degli Studi di Roma La Sapienza (Italy) 
8773 OR Transmitting continuous variable entangled states over long distances [8773-33]

G. Nocerino, D. Buono, Univ. degli Studi di Salerno (Italy); A. Porzio, CNR, SPIN, Complesso

Univ. (Italy); S. Solimeno, Univ. degli Studi di Napoli Federico II (Italy)

\section{SESSION 6 SOURCES OF NONCLASSICAL STATES OF LIGHT}

8773 OS An extremely low-noise heralded single-photon source without temporal post-selection [8773-34]

F. Piacentini, P. Traina, Istituto Nazionale di Ricerca Metrologica (Italy); A. Della Frera,

A. Tosi, C. Scarcella, A. Ruggeri, A. Gulinatti, M. Ghioni, Politecnico di Milano (Italy);

S. V. Polyakov, A. Migdall, Joint Quantum Institute, Univ. of Maryland and National Institute of Standards and Technology (United States); A. Giudice, Micro Photon Devices S.r.l. (Italy);

G. Brida, I. P. Degiovanni, M. Genovese, Istituto Nazionale di Ricerca Metrologica (Italy)

8773 OW Generation of nonclassical light by nonlinear cavities [8773-38]

T. Häyrynen, J. Oksanen, T. Sadi, J. Tulkki, Aalto Univ. (Finland)

\section{SESSION 7 QUANTUM OPTICS}

8773 OY Signatures of the collapse and revival of a spin Schrödinger cat state in a continuously monitored field mode [8773-41]

R. D. Wilson, M. J. Everitt, Loughborough Univ. (United Kingdom); W. J. Munro, NTT Corp. (Japan); T. P. Spiller, Univ. of Leeds (United Kingdom)

$87730 Z$ Propagation of Raman-resonant frequency chirped laser pulses in a medium of lambdaatoms [8773-42]

N. Sandor, G. P. Djotyan, Wigner Research Ctr. for Physics (Hungary)

877310 Two-atom system as a directional frequency filter [8773-43]

V. E. Lembessis, A. Al Rsheed, King Saud Univ. (Saudi Arabia); O. M. Aldossary, King Saud Univ. (Saudi Arabia), and King Abdulaziz City for Science and Technology (Saudi Arabia);

Z. Ficek, King Abdulaziz City for Science and Technology (Saudi Arabia)

877311 Measurement of hyperfine splitting and determination of hyperfine structure constant of cesium $\mathbf{8 S}_{\mathbf{1 / 2}}$ state by using of ladder-type EIT [8773-44]

J. Wang, J. Wang, H. Liu, B. Yang, J. He, Shanxi Univ. (China)

877312 Noiseless amplification of weak coherent fields without external energy [8773-46]

M. Partanen, T. Häyrynen, J. Oksanen, J. Tulkki, Aalto Univ. (Finland)

POSTER SESSION 2

877313 Influence of hydrostatic pressure on electronic states and optical properties of spherical quantum dots [8773-45]

D. B. Hayrapetyan, Russian-Armenian State Univ. (Armenia) and State Engineering Univ. of Armenia (Armenia); E. M. Kazaryan, H. K. Tevosyan, Russian-Armenian State Univ. (Armenia) 
877314 The simple theoretical analysis of quantum well wires superlattice (QWSL) of communication technology [8773-47]

S. Singha Roy, West Bengal Univ. of Technology (India)

Author Index 


\title{
Conference Committees
}

\author{
Symposium Chairs \\ Jiri Homola, Institute of Photonics and Electronics of the ASCR, v.v.i \\ (Czech Republic) \\ Chris Edwards, Central Laser Facility, Science and Technology \\ Facilities Council (United Kingdom) \\ Mike Dunne, Lawrence Livermore National Laboratory (United States) \\ Ivo Rendina, Instituto per la Microelettronica e Microsistemi, CNR \\ (Italy) \\ Honorary Symposium Chair
}

Miroslav Miller, Institute of Photonics and Electronics of the ASCR, v.v.i (Czech Republic)

\section{Part A Photon Counting Applications IV}

\section{Conference Chairs}

Ivan Prochazka, Czech Technical University in Prague (Czech Republic)

Roman Sobolewski, Institute of Electron Technology (Poland), and University of Rochester (United States)

Conference Programme Committee

Josef Blazej, Czech Technical University in Prague (Czech Republic)

Ulrich Schreiber, Technische Universität München (Germany)

Valery Zwiller, Technische Universiteit Delft (Netherlands)

\section{Session Chairs}

1 Solid State Photon Counting

Ivan Prochazka, Czech Technical University in Prague

(Czech Republic)

2 Photon Counting Applications I

Ralph B. James, Brookhaven National Laboratory (United States)

3 Photon Counting Applications II

Valery Zwiller, Technische Universiteit Delft (Netherlands) 
4 Superconducting Photon Counting

Roman Sobolewski, Institute of Electron Technology (Poland), and University of Rochester (United States)

\section{Part B Quantum Optics and Quantum Information Transfer and Processing}

Conference Chairs

Jaromír Fiurásek, Palacký University Olomouc (Czech Republic)

Conference Programme Committee

Ulrik Andersen, Technische Universiteit Delft (Denmark)

Marco Bellini, Istituto Nazionale di Ottica (Italy)

Nicolas J. Cerf, Université Libre de Bruxelles (Belgium)

Miloslav Dusek, Palacký University Olomouc (Czech Republic)

Jens S. Eisert, Universität Potsdam (Germany)

Alexander I. Lvovsky, University of Calgary (Canada)

Jeremy L. O'Brien, University of Bristol (United Kingdom)

Geoff J. Pryde, Griffith University (Australia)

Fabio Sciarrino, Università degli Studi di Roma La Sapienza (Italy)

Andrew J. Shields, Toshiba Research Europe Ltd. (United Kingdom)

Juan P. Torres, ICFO - Institut de Ciències Fotòniques (Spain)

\section{Session Chairs}

5 Optical Quantum Information Processing

Jaromír Fiurásek, Palacký University Olomouc (Czech Republic)

6 Sources of Nonclassical States of Light

Jaromír Fiurásek, Palacký University Olomouc (Czech Republic)

7 Quantum Optics

Jaromír Fiurásek, Palacký University Olomouc (Czech Republic) 